Article

\title{
Decentralization Drivers beyond Legal Provisions: The Case of Collaborative Forest Management in Java Island
}

\author{
Wiene Andriyana $\mathbb{D}^{\mathbb{D}}$ and Karl Hogl * \\ Institute of Forest, Environmental and Natural Resource Policy, University of Natural Resources and Life \\ Sciences, Vienna; Feistmantelstrasse 4, 1180 Vienna, Austria \\ * Correspondence: karl.hogl@boku.ac.at
}

Received: 17 July 2019; Accepted: 11 August 2019; Published: 14 August 2019

check for updates

\begin{abstract}
This study analyzes the impact of the Indonesian government's decentralization policy and movement on the state forest community involvement program on the island of Java from 2000 to 2014. For more than 30 years, approximately 76 percent of the state-owned forests in Java, covering 2.4 mio. hectares (5.9 mio. acres or 9,266 square miles), or 42 percent of the forests in Java, were exclusively managed by the State Forest Company (SFC). The general perception was, and largely still is, that the decentralization era reforms had little or no effects in Java, simply because the national decentralization regulations essentially maintained this dominant role. Thus, possible effects were hardly examined. This study aims to fill this gap by analyzing whether the national decentralization movement and policy affected and changed the policies and practices of involving local actors and communities in Java's state forest governance and management. Our analytical framework follows the Policy Arrangement Approach (PAA), comprising four main analytical dimensions for assessing change and stability: The actors involved; the distribution of power and resources; the existing and applied rules; and discourses concerning the topic of research. The analysis is based on an extensive review of scholarly literature and policy documents, as well as 73 in-depth interviews with actors, from the national to the local levels, of two districts in Central Java. Overall, our findings show that the nationwide decentralization movement significantly affects the modes of collaborative forest management in Java, much more than one would expect if only looking at changes in the respective legal texts. The movement fueled changes, inter alia, by promoting discourses on sustainable forest management for local development, and triggering the revival of grassroots movements further empowered by local non-governmental organizations (NGOs), as well as by triggering the formal institutionalization of the informal norms and practices of local communities. New actors entered the arena, and the distribution of power, resources and benefits drawn from state forest management has changed in favor of district authorities and local communities at the expense of the State Forest Company.
\end{abstract}

Keywords: forest policy; forest governance; collaborative forest management; decentralization; policy arrangement approach

\section{Introduction}

Decentralization of natural resource governance and management, a practice considered central in many governance reforms, has become increasingly popular in a number of countries since the mid-1980s [1,2]. In the last twenty years, efforts have been made throughout the world to enhance forest governance by changing forest tenure and encouraging decentralization in decision-making [3].

Forests are important in this regard, because they are closely linked to other key resources, such as land, biodiversity and water [4]. Accordingly, forest governance was the most studied theme in the 
literature on natural resource decentralization [4] (p. 214), resulting in a complex and varied body of literature [5].

In Indonesia, during the period 1998-2000, the overall governance system underwent dramatic changes through the adoption of a national decentralization policy during the course of the overall national reformation movement. The overarching policy was tailored to various development sectors, including forestry. Before then, for more than three decades, forests had been managed in a state-centered system, and decisions were made top-down. Most financial benefits and decisions were in the hands of the central government. This situation triggered a movement that called for benefits and power to be moved to local governments and communities. As a result, the reformation government issued the Law on Regional Governance (Law No. 22/1999) [6], followed by the issuance of various other implementation regulations that also addressed forest governance and management. However, these regulations did not directly transfer authority to local communities. The Ministry continues to administer and manage all nationally important protected areas. The authority over other forest areas, including watershed forest, production forest and locally protected forests, was partly devolved to the district level. However, this was not the case for the island of Java.

The administration of the forestry sector in Java was and still is unique, characterized by the long-term dominance of the state forest company (SFC) Perum Perhutani. Government Regulations 15/1972 and 72/2010 provided the SFC with the exclusive mandate to further manage all state-owned production and protection forest in Java. While regional state institutions in other parts of Indonesia, such as the Provincial and District Forest Authorities, were legally affected by the enactment of various regulations on decentralization, in Java, the SFC still enjoys the position of exclusive state forest manager. Consequently, many studies have been conducted on the processes and outcomes of decentralization in other parts of Indonesia, but hardly any in-depth studies have been conducted in the context of Java.

Notwithstanding this unique situation, the euphoria of decentralization was also strong in the communities of Java, particularly among people who live close to SFC-managed forests. Despite the formal continuation of the SFC's exclusive management authority, as set out by the decentralization regulation, several studies have suggested that the general decentralization movement affected the SFC in various ways $[7,8]$. In fact, the SFC changed some internal policies regarding its relationship with local communities. Local news and publications also reported conflicts between the SFC and forest communities, and between the SFC and district governments, partly triggered by conflicting perceptions about how decentralization should work in practice (see, e.g., [9-12]).

Nevertheless, the number of studies specifically addressing the decentralization of forest governance in Java is still quite limited $[7,8,13,14]$, while studies on the Outer Islands provide in-depth accounts of new modes of governance and their effects upon the biodiversity-rich tropical forests there [15-24]. However, studies on the Outer Islands do not allow lessons to be drawn for Java because of the unique position of the SFC and the very different natural characteristics of the forests.

This study aims to further fill this gap by analyzing the processes and impacts of the decentralization of forest governance and management in Java. The core question that guides our analysis is whether and how the national decentralization policy and movement triggered changes in the relationships between the central state, lower level authorities and local communities, which are active in and affected by forest governance and management.

\section{Research Framework, Research Design and Methods}

This study aims to capture the processes and impacts of the Indonesian decentralization policy on forest governance and management in Java Island. As a baseline, we broadly define "decentralization policy" as referring to any formal regulation enacted by a governmental institution that introduces the idea of, endorses the application of, or implements decentralization in the field of forest policy. 
Following Jann and Wegrich [25] (p. 79) we define "policy impact" as changes in actors' behavior in response to a policy output (e.g., a provincial decree), for example, by establishing forums for community participation.

The Policy Arrangement Approach (PAA) offers comprehensive analytical perspectives to analyze such processes and related impacts. It was developed in response to new perspectives, concepts and vocabulary in policy studies [26]. While new concepts, such as governance, discourses, policy networks and related theorizing, started to dominate the discipline in the late 1990s, certain aspects [26] (p. 340) seemed to become increasingly overlooked, aspects well-captured by terms such as power, state, government and authority (ibid.). Thus, the PAA aims to provide an analytical framework "to understand shifts in governance on the one hand, and to preserve some of the relevant classical concepts on the other" (ibid.). In its early years, the PAA was particularly applied to research the dynamics of Dutch environmental policy-making in the late 1990s [27], setting out to capture temporary stabilizations and changes of the content and the organization of the policy arrangements. Since then, it has proven useful for studying the phenomena of change and stability in the fields of environmental and natural resource policy, including forest policy, mainly in the European context [28-30]. Applications to cases outside of Europe are relatively recent [31-35].

The concept of policy arrangement refers to "the way in which a policy domain is shaped in terms of organization and substance, in a bounded time-space context" and allows researchers to analytically address change and stability in a policy field [26] (p. 341) by four interrelated analytical dimensions: Policy discourse, policy actors and actor coalitions, power and the dimension of resources (intrinsically linked to the concept of power) [27].

While the policy-related discourse dimension of the PAA addresses the content (e.g., program narratives, goals and ideas to solve problems), the organizational dimensions comprise: (1) Policy actors and coalitions (including actor-interactions), (2) their power and resources and (3) the rules of the game (i.e., institutions) [27].

We have chosen the PAA as our theoretical framework for the following reasons: It calls for and facilitates researching changes in both policy and governance, i.e., in the content and the interactions of actors, by paying attention to the organizational, as well as the discursive aspects of the decentralization process, and it pays due attention to the role of the socio-economic context of decentralization, which is important in case study research [36].

Following Buizer [37], we understand discourses as the way problems are perceived and constructed by those who take initiatives and those who represent established policies. Generally, a discourse refers to concepts, ideas, views, buzzwords and the like, which give meaning to a policy domain [27] (p. 56). Leaning on Arts and Buizer [29] (p. 341), our study operationalizes discourses as frames and social practices. Discourse as frames exists in the minds of people and in the social networks they belong to. These discourses influence how actors speak about and act upon a phenomenon [29] (p. 342). Looking at discourses as social practices asks how they are intertwined with and manifest, e.g., in institutional arrangements and power processes [29] (p. 342).

Regarding actors, the PAA necessitates identifying relevant actors and their influence in a policy domain [38], distinguishes central and peripheral (fringe) players in concrete actor constellations [39] (p. 329), and hints at the interaction of actors and actor coalitions, which may share certain policy discourses and resources [27] (p. 57).

To further operationalize the actor dimension, we partly borrowed concepts from the framework of 'Actor-Centered Institutionalism' [40], characterizing actors by their capabilities and orientations. "Capabilities" refer to resources that actors can use to influence decisions. Thus, "power" rests on the mobilization of resources [38] (p. 47). The orientations of actors are assumed to rest on their perceptions and preferences with regard to the decision being made [38] (p. 43). At the level of a policy field, the plurality of "players" involved establishes a specific actor constellation, with each actor characterized by specific resources, orientations and strategy options to pursue preferred outcomes [38] (p. 44). 
Questions to address in analyses include: (1) How power and resources are distributed in a policy arrangement; (2) how this distribution may have changed over time; and (3) how discourses and discourse changes affected the distribution of power among actors [27] (p. 61).

The PAA understands "rules" as formal procedures as well as informal routines that are mutually agreed upon [38] (p. 56). In any policy arrangement, actors constantly draw upon rules that provide guidance for acting properly [27] (p. 61). Rules allow and enable certain practices, while potentially impeding or prohibiting others. For this study, we define 'formal rules' as those that are defined and authorized in legal texts or other binding documents, whereas 'informal' rules are part of a predominant—but potentially more fluid—political culture [27] (p. 61), including social norms, customary practices or traditional routines that are perceived as legitimate, and are broadly accepted by the actors concerned without being codified.

This research aims to provide a grounded case-based empirical study on forestry decentralization, covering the period from 1998 to 2014. The empirical research for this paper comprises two stages of fieldwork, conducted in 2013 and 2014. A first exploratory phase aimed to specify our research questions more precisely, and to select forest governance mechanisms and regions for in-depth case study research. Furthermore, respective core stakeholders were identified in this exploratory phase. This first stage of fieldwork was based upon a comprehensive literature review and document analysis, including gray literature and locally available, often unpublished materials, and on qualitative interviews with experts at the national, provincial and district levels. Stage two then focuses on collecting data for selected forest governance and management mechanisms in chosen districts, again by means of qualitative in-depth stakeholder interviews, observations, some group discussions and the collection of local documents, regulations and other written materials only accessible on-the-spot. In total, 73 key informants were interviewed, representing organizations and expertise as listed in the Appendix A. These informants represent experts and stakeholders at the national, provincial, district and village levels, as well as govern-mental and nongovernmental organizations.

All interviews were recorded and transcribed for qualitative analysis (together with many documents). Based on our research questions, a first coding scheme was deductively derived from the analytical framework, and further elaborated and refined inductively during the analysis, informed by the empirical data. The analysis was assisted by MAXQDA10 (VERBI Software GmbH, Berlin, Germany).

In terms of the empirical phenomena and location, this study investigates changes in the Collaborative Forest Management Program (CFMP) of the SFC in two forest-rich districts of Central Java: The Blora and Kendal Districts. The level of districts was chosen for analysis because the decentralization policy aimed to delegate forest authority at that level. Thus, the assumption is that if there are significant changes to be found, they should be found at this level.

This paper acknowledges that by 2014, the revision of the law on decentralization (Law of the Republic Indonesia No. 23 Year 2014 concerning Local Government, issued: 2 October 2014) transferred some authority regarding natural resource governance from district to provincial authorities. However, the respective changes are not pertinent to this paper; all fieldwork was done before this particular reform.

Both districts are home to valuable state-forest resources while featuring quite different biophysical, socioeconomic and historical contexts. These two districts are deliberately selected to obtain, via comparison, some insight into the potential relevance of these differences. The Blora District extends over 182,058 hectares (449,875 acres, or 703 square miles), 50 percent of which is forested, and is dominated by state forests ( 99 percent). The Kendal District, in contrast, has a size of 100,223 hectares (247,656 acres, or 387 square miles), 19 percent are forested, and 83 percent of the forests are state-owned. Blora generally features dry and barren soil conditions and extremely low precipitation, especially in the dry season, making it suitable for the cultivation of high-value teak. Accordingly, the forestry undertaken by the SFC and local communities focuses upon the production of teak timber, and the cultivation of other slow-growing species (Swietenia mahagoni (L.) Jacq, locally called "mahoni"). 
Kendal district, in contrast, features a wet climate and is considered an agricultural area, dominated by paddies.

Tree species cultivated in Kendal are primarily fast-growing ones, such as Paraserianthes falcataria (locally "sengon"). High-value teak is cultivated to a limited extent only, some on private lands, and to a larger extent by the SFC. Compared to the Kendal District, the communities in the Blora District have a strong and long historical connection to their forests, particularly due to the low fertility of the soils and dry conditions that do not allow cultivating rice or other agricultural products. Instead, they have to rely on forestry-related activities for their livelihood. The literature and results of the exploratory fieldwork indicate that specific differences in the biophysical characteristics of forests strongly affect the forest-related activities of local communities and of state forest managers [41,42]; (Interview sources: $\mathrm{I}_{17} ; \mathrm{I}_{34} ; \mathrm{I}_{42} ; \mathrm{I}_{52} ; \mathrm{I}_{56}$ (code: Ix stands for "interview/informant number $\mathrm{x}$, as listed in Appendix A. $\mathrm{I}_{17}$, for example, refers to information given by informant number 17 according to the list)).

Only by knowing the historical context of the policy domain can we accurately analyze and understand the impact of the decentralization policies [43] in our cases. The importance of the historical context to understanding changes in forest governance and management in Indonesia is specifically highlighted in the work of Peluso (1992), Large (2005) and Nurjaya (2005) [44-46]. These authors underline how strongly historical developments shape current policy-making and practices. With regard to Java, the role of state forest authorities and the SFC from the early years of Indonesia's independence until today cannot be understood without reference to the colonial past [47] (p. 5).

Starting with Dutch colonialism in 1596, and continuing beyond the foundation of the Indonesian Republic in 1945, forests were controlled and managed by the central government at the expense of local access and benefits [45]. The main interest of the colonial rulers was to extract high-quality teak timber for shipbuilding. The dominance of the Dutch East India Company (VOC), particularly its monopoly over the management of Java's teak forests in the 17th and 18th centuries, strongly affected the forests. By the mid-eighteenth century, all of Java was occupied by the Dutch, who controlled all timber-rich districts and the local labor force for the purpose of extracting timber. The colonial government declared all forests state property under the Basic Agrarian Law of the 1870s, which stated that the Dutch government owned all of the land for which there was no legal proof of any other ownership [48].

In the late nineteenth and early twentieth centuries, an organization of professional, 'scientifically'-trained foresters, who also had strong police training, laid the foundations of state forest management. German foresters were sent to Java to introduce science-based forest management. During the short Japanese period (1942-1945), many forest resources were destroyed: Japan's interest focused on timber extraction to support warfare in the Far East.

In the aftermath of the independence of the Republic of Indonesia in 1945, all rights and obligations concerning forest management in Java, previously held by the Dutch Indies, were transferred to the Republic of Indonesia. Forest laws were translated from Dutch into Indonesian without substantive changes, and separate branches of a state enterprise for managing teak forests were formed in Central and East Java (1961). Finally, in 1978, the State Forestry Company (SFC) was established to manage all of Java's forests [49]. Since then, the SFC has controlled all activities within state forests, and restricted access to them by exercising preventive, coercive and repressive military approaches $[44,49]$. The SFC responded-in a military style—to any activities considered 'illegal' [49,50], e.g., the collection of firewood, grazing and the destruction of seedlings, as well as to any signs of tree theft and damage.

To summarize, for a very long time, from colonial times until the reformation era of the late 1990s, communities living in the vicinity of state forest areas and the local authorities were formally excluded from the governance and management of these forests, and from benefiting from the products and earnings derived from these forests.

However, the SFC also introduced programs ostensibly intended to involve local people in managing state forests. Such community-involvement programs were introduced under different 
names, starting with the Prosperity Approach program in the 1970s. These programs provided communities with the only legal mechanism to benefit from state teak forests.

Irrespective of changes in the title of these programs and other changes, the SFC's fundamental idea of community involvement basically remained the same: To employ locals for cultivating and maintaining tree seedlings in exchange for very low wages and permission to cultivate subsistence crops under the trees for certain periods of time, usually for two years $\left(\mathrm{I}_{17} ; \mathrm{I}_{29}\right)$. Only after the reformation era, in 2001, when the SFC launched the Collaborative Forest Management Program (CFMP), did more significant changes take place. These changes are of central interest in this study.

Various forms of community involvement have been developed and implemented in forest management around the world in the last decades, ranging from purely community-based management to manifold modes of community involvement and some participation in state forest management. Such programs usually claim to improve the local people's livelihood and to conserve the forests [51]. A lot of research was conducted to shed light on their actual performance and the factors that might explain cases of success and failure. Arts and De Koning (2017) provide a good overview and characterization of the vast body of scholarly literature [51]. There is consensus that the performance is mixed overall (ibid.), and scholars found a sizeable list of factors that were highly relevant in the case that they studied, such as the biophysical context, demographic development, economic interest and benefits that can be drawn by communities, clarity of ownership rights and rules for forest use and external support (ibid.).

\section{Results: Changes Triggered by Decentralization}

\subsection{New "Rules of the Game"}

The decentralization policy has not formally affected the role of the SFC in managing the state's production and protected forests in Java. However, due to pressures from an informal process and the general enthusiasm for reformation and decentralization, the SFC introduced at least five formal regulations concerning the involvement of forest communities between 2001 and 2011 [52-56].

"SFC had no options but to follow the decentralization mainstream by introducing the Collaborative Forest Management Program. This was triggered, by, among other factors, massive forest destruction, pressure from NGOs and district governments, and community awareness. So, the CFMP did not originate from changes in the SFC mindset. But in the past 10 years, the SFC has become more aware that they cannot manage Java's forests alone, although this [change in awareness] may not be the case at all levels within the SFC." $\left(\mathrm{I}_{62}\right.$, translated by the author)

The implementation of the CFMP is purely based on SFC-internal regulations [52-56], once again proving the power of the SFC in determining the communities' access to forest resources. This situation also shows that the initiation of the CFMP in the SFC's working areas was not required by any state regulation. Only one provincial regulation [57] refers to the CFMP, emphasizing the need for all stakeholders to support the SFC's CFMP scheme, particularly calling for support by district forest authorities. However, following the administrative decentralization reforms, district forest authorities are not accountable to the provincial authorities; hence, the provincial regulation cannot guarantee support by district forest authorities $\left(\mathrm{I}_{11}\right)$.

In addition to the internal policies of the SFC and the provincial regulation mentioned above, some additional formalized documents guide the establishment and day-to-day practices of the CFMP: (1) Notarial deeds concerning the establishment of Forest Village Community Organizations (FVCOs); (2) collaboration agreements between the SFC and FVCOs (Perjanjian Kerja Sama, PKS); and (3) Memoranda of Understanding (MoU) between the SFC and the FVCOs.

All of the aforementioned rules determine the distribution of power and resources among CFMP actors. They regulate (1) access to the state forests; (2) planting and cultivation schemes within the state forestlands (e.g., defining the schedules, species and methods of cultivation); (3) the maintenance 
of teak tree seedlings; (4) harvesting of non-timber forest products and drawing other benefits from state forestlands; and (5) schemes concerning the sharing of benefits from the SFC's timber production. In general, although these CFMP regulations mention that the collaboration agreements should be co-developed between the communities and the SFC, in practice, the SFC has taken the lead in developing all of these agreements, i.e., in a top-down process $\left(\mathrm{I}_{17} ; \mathrm{I}_{29} ; \mathrm{I}_{32} ; \mathrm{I}_{47} ; \mathrm{I}_{48}\right)$.

In contrast to previous community involvement programs, the CFMP rules provide some room for negotiation in the forest community group's forums, although only to a limited extent, and village representatives are involved in the forum. However, as will be discussed, some informal rules can overcome the remaining limitations.

In terms of formal rules, there are at least three significant changes to the practices of community involvement in state forest management. First, the collaboration arrangement between the SFC and the communities was formalized from an informal, verbal commitment to written contracts. This formalized Memorandum of Understanding (MoU) provides a much more secure scheme of collaboration for the communities. Second, there is now an obligation to establish the FVCO by a notarial deed, an obligatory step before anyone can participate and utilize forestland. There are now committees of representatives of the villages and the SFC. Previously, the SFC targeted individuals, e.g., farmers who were directly involved in forest-related activities, to create informal forest farmers' groups in a top-down approach to coordinating field activities. The work of these former groups was heavily dependent on verbal commitments from SFC personnel $\left(I_{63}\right)$.

In the new CFMP mode, entire villages are now potential beneficiaries, even beyond land-based or forest-related activities $\left(\mathrm{I}_{22} ; \mathrm{I}_{57} ; \mathrm{I}_{63}\right)$. All villagers are members of the FVCO, which is led by a board, elected in village meetings, facilitated by the SFC, and acts on behalf of all members.

The third change, and perhaps the most significant added-value brought about by the new CFMP, is the sharing of the financial benefits of timber production. Beforehand, communities could only benefit from non-timber forest products cultivated under teak trees, in accordance with certain rules defined by the SFC. The new mode also offers financial benefits for communities of up to 25 percent of the value of the timber harvested from the SFC's working areas located next to villages. Because of the high value of teak timber, these are significant amounts for the villages. Interestingly, the SFC was willing to waive this much money in the spirit of 'sharing', although there is no regulation that obliges the SFC to forego this income. However, because of other pressures, they finally opted to do so. Massive quantities of timber theft, forest-related crimes and the dismissal of their FSC certification, were among the factors that had pressured the SFC to meet the communities' requests to this extent. These payments must benefit the entire village, not only those individuals who are directly involved in forestry. They are typically used, for example, in the development and maintenance of infrastructure, such as health care and education facilities, the establishment of village-owned businesses, and for various social activities. The boards of the FVCO manage the respective budgets.

Furthermore, our fieldwork revealed that there are other mechanisms that allow certain groups, mostly landless farmers, to benefit from state forests without obeying the formal rules as defined by the SFC, i.e., without joining an FVCO as per the requirement of the CFMP. Some farmers refused to join the FVCO, but created their own forest users' group $\left(\mathrm{I}_{17} ; \mathrm{I}_{29} ; \mathrm{I}_{32} ; \mathrm{I}_{47}\right)$. The emergence of these independent, grassroots forest user groups was also triggered by the decentralization movement. Principally, these grassroots groups are not afraid to resist the SFC's rules for co-utilizing state forests, for example, the rules for selecting species to be planted, and the rules specifying the land where the groups are allowed to cultivate crops $\left(\mathrm{I}_{17} ; \mathrm{I}_{29} ; \mathrm{I}_{32} ; \mathrm{I}_{47}\right)$. These grassroots groups occupied small areas of SFC forests (approximately a quarter-hectare to one hectare) and cultivated them with various subsistence crops for their livelihood. They simply cultivate any cash-crop species they wish to grow and normally use a very dense planting space to achieve the maximum yield, very much against the SFC's rules. This practice is certainly not in agreement with the formal rules of community involvement in SFC working areas. However, the SFC was forced to adjust to these scattered illegal practices. Although aware of this problematic and formally illegal situation, the SFC has not taken any strong measures to tackle it, 
as they have done in similar situations previously, e.g., in collaboration with military authorities. These kinds of illegal yet accepted practices-i.e., cultivating in the SFC's working areas without joining any CFMP scheme- -have been practiced and observed in both research districts since the early part of the reformation era.

The community's resistance to the limitations set by the SFC was much stronger in Blora District than in Kendal. This difference was due to long-held grassroots values in land management (the Samin Movement) and the existence of the NGO Arupa, which has long supported the local grassroots community Lidah Tani, particularly in Temulus village, known as the origin of the Samin movement. As described by the leader of the grassroots movement $\left(\mathrm{I}_{32}\right)$ and confirmed by SFC personnel $\left(\mathrm{I}_{67}\right)$, followers of Samin values openly use state forestland to cultivate crops for their needs. Samin farmers believe that God has given the land to support the welfare of the people. Therefore, the people are entitled to benefit from the land. As explained by SFC personnel $\left(\mathrm{I}_{67} ; \mathrm{I}_{40} ; \mathrm{I}_{63}\right)$, members of this group do not hesitate to resort to violence against SFC officers, and refuse to communicate with SFC representatives $\left(\mathrm{I}_{22} ; \mathrm{I}_{32} ; \mathrm{I}_{63}\right)$. In daily life, members of the grassroots movement live in harmony with the other villagers, the members of the SFC-based FVCO. To avoid further conflict, the SFC minimized contact with this grassroots movement, letting them pursue their agricultural activities within the state forest areas without any agreement and without any limitations $\left(\mathrm{I}_{67} ; \mathrm{I}_{40} ; \mathrm{I}_{63}\right)$.

In the Kendal district, partly due to local values and wisdom emphasizing 'treating other people with respect and politeness', no extreme form of resistance was observed $\left(\mathrm{I}_{10}\right)$. Members of a grassroots farmers group were communicating with SFC personnel, but without necessarily obeying SFC instructions. The leader of the grassroots movement was well informed about the situation in Blora district (and also attended regular meetings of Central Java movements, supported by pro-community NGOs) $\left(I_{17} ; I_{29} ; I_{47}\right)$. While in Blora, the group rejected any communication with the SFC, the grassroots movement in Kendal renegotiated their access to and benefits from the nearby state forests with the SFC. Without the need to accede to the FCVO, the grassroots farmer group secured a 'specially arranged' Memorandum of Understanding with the SFC, acknowledging their status as an independent farmer group and the right to negotiate the crops planted and planting techniques in state forestland $\left(\mathrm{I}_{17}\right.$; $\left.\mathrm{I}_{29} ; \mathrm{I}_{47}\right)$.

The changes in behavior of the SFC and the grassroots movements, as described above, can be explained by changes in power relations and in resource endowments among the actors, as described in the next section.

\subsection{New and Strengthened Actors}

The establishment of new district-based forest state agencies, as mandated in Law 22/1999 [6], has formally marked the decentralization era in Java's forestry sector. The heads of these new district institutions are only responsible to the Head of District, but not to the Provincial Forest Authorities and the state government. District forest authorities (DFAs) have their own budgets, allocated by district governments. The definition of the name and the scope of activities of these new institutions are up to the district governments, including whether they work on forestry matters only, or also handle affairs such as fisheries and animal husbandry.

Thus, a new actor has entered Java's state forest governance arena, formally based on a decentralization policy. The SFC had to admit that they must involve the district authorities in community programs. Prior to the reform, there was a notion that the position of the SFC in the districts was like 'a kingdom inside a kingdom' $\left(\mathrm{I}_{2} ; \mathrm{I}_{62}\right)$, indicating that the SFC worked very independently in the areas under the jurisdiction of districts.

Decentralization has revived the collective consciousness that forest-dependent people are members of the communities belonging to the district governments, whether they live next to SFC forests or not $\left(\mathrm{I}_{46} ; \mathrm{I}_{56}\right.$ - see quote below); thus, the broadly held belief is that district authorities have to be involved in the CFMP, a program that aims to improve the communities' wealth and livelihood. A head of an SFC-district office described this reasoning as follows: 
"Decentralization is something that the SFC cannot resist. We should not view decentralization as a positive or a negative issue for the SFC. Instead, we must go with the decentralization flow. We should now think of how the decentralization movement's energy could create positive impacts, and this should be seen as an opportunity for the SFC. However, some people may also see this as a burden. This, again, is an opportunity. Before [decentralization], the general view was that the forest community was merely the SFC's community."

"Now the Head of the District can also see that this community is also a District's community. Therefore, there is indeed interdependency between the SFC and the District Government." ( $\mathrm{I}_{56}$, translated by the author)

Consequently, the SFC has involved the DFA in their CFMP, but with limited authority and a largely passive role. The DFA has become a member of the Communication Forums, along with other district institutions and local NGOs, and has been invited to ceremonies to share the benefits of timber production. To mediate conflicts with villagers, the SFC also consults with DFAs. Some key informants consider this DFA involvement to be an SFC effort merely intended to legitimize the CFMP $\left(\mathrm{I}_{1} ; \mathrm{I}_{6} ; \mathrm{I}_{46}\right.$; $\mathrm{I}_{48}$ ). Nevertheless, many types of involvement create room for interactions between the SFC and the district authorities, something that did not happen before.

Although the DFA's role could be considered passive, its involvement indicates the acknowledgement of DFAs by the SFC. In practice, the support of the DFAs is needed to prevent and mediate conflicts with the communities $\left(\mathrm{I}_{34} ; \mathrm{I}_{56}\right)$. In addition, DFAs also facilitate connecting CFMP activities to the activities of other units of district governments $\left(\mathrm{I}_{57}\right)$, easing coordination and cooperation at the district level ( $\left.\mathrm{I}_{34}\right)$; $\mathrm{CFMP}$ activities may relate, for example, to the establishment of village cooperatives or cattle farms. In such cases, the SFC can resort to support from DFAs for coordination with the district authorities responsible for cooperatives and animal husbandry $\left(\mathrm{I}_{57}\right)$.

The decree of the Central Java Governor No. 24/2001 [57] states that with regard to the CFMP, the district government must (1) facilitate and empower the communities surrounding the forest; (2) secure all state forest assets within their territory; (3) facilitate program activities; and (4) together with the SFC, communities and other stakeholders, make efforts to optimize and further expand CFMP activities (Article 15: 2). Both provincial and district forest authorities could apply this regulation to allocate district budgets in support of the CFMP $\left(\mathrm{I}_{15}\right)$.

In Blora district, the DFA allocated budgets to support CFMP activities, for example, for providing tree-farming training, for the CFMP Communication Forum $\left(\mathrm{I}_{34}\right)$, and to increase the capacities of the FVCOs [58]. At the provincial level, the Central Java Forest Authority allocated approximately US\$ 35,000 in the 2013 budget to support the CFMP by empowering the FVCOs [59].

The DFA of Kendal occasionally provided free-of-charge seedlings for CFMP planting activities $\left(\mathrm{I}_{60}\right)$ to support a specific land rehabilitation project of the Ministry of Forestry $\left(\mathrm{I}_{10} ; \mathrm{I}_{19}\right)$. In summary, while there is no formal basis for doing so, neither in state regulations nor in SFC policy documents, DFAs in both districts have established a certain bargaining position vis-á-vis the SFC in the implementation of the CFMP.

"After the reformation, the role of the NGOs became increasingly important. It is widely known that an NGO is an obligatory actor that must be involved in any process, including the CFMP process. Why? It is needed for the SFC to legitimize the CFMP." $\left(\mathrm{I}_{1}\right.$, translated by the author)

Like that of the DFAs, the role of locally-active NGOs has changed in the course of the reformation process. Supported by international donors, their position has shifted from having little influence to enjoying a great deal of influence in CFMP implementation. They strongly influenced and supported the empowerment of the grassroots movement by providing information about the SFC and CFMP and introducing ideas of agrarian reform to the communities $\left(\mathrm{I}_{17} ; \mathrm{I}_{29} ; \mathrm{I}_{32} ; \mathrm{I}_{48}\right)$. As confirmed by a high SFC official, NGOs have been very critical of SFC activities, and have closely observed them since the early reformation era $\left(\mathrm{I}_{61}\right)$, particularly those activities affecting communities. Even minor SFC 
mistakes can result in allegations and protests $\left(\mathrm{I}_{61}\right)$. The NGOs' involvement made it increasingly important for the SFC to legitimize the multi-stakeholder process in the CFMP $\left(\mathrm{I}_{1}\right)$. Furthermore, in some areas, the SFC also collaborated with the local NGOs to assist its communication with the forest communities, and to secure their commitment to the CFMP $\left(\mathrm{I}_{1} ; \mathrm{I}_{22} ; \mathrm{I}_{67}\right)$.

\subsection{Changes in Power and Resources}

In formal terms, the SFC holds great power over the practices of the CFMP because of (1) the formal rights as set out in the regulations, including formal authority and control over the state forests' land as the key input for conducting the CFMP; (2) its skills, knowledge and information with regard to the forest and forestry techniques; and (3) and the human resources at its disposal, from central administration down to field-level operations. Other actors of the CFMP have not been significantly empowered by formal regulations. However, as will be discussed below, in practice, their informal power is considerable, and is taken into account by the SFC.

The CFMP has indeed changed the way in which actors are able to interact with SFC personnel. The change was strongly supported by pressure put on the SFC, resulting from massive illegal logging in state forests at the beginning of the reformation era. Large-scale timber theft events led to deadly conflicts between armed SFC guards and villagers [48,60-63]. The conflict and significant loss of forest area resulted in international pressure, e.g., pressure imposed by the Forest Stewardship Council (FSC), which finally withdrew the certificate for sustainable forest management in 2001 [64,65]. In the course of all these struggles, the communities have become more confident in standing up for and defending their interests, further spurred by the economic crisis that hit them during that time, especially between 1998 and $2003\left(\mathrm{I}_{32} ; \mathrm{I}_{44}\right)$. Community members in both the Kendal and Blora districts explained the situation as follows:

'We had started to occupy and cultivate the SFC's land, in the absence of any agreement, when the economic crisis hit us. It began when we, the villagers, witnessed a lot of bare land, resulting from illegal logging. At first, we were reluctant to cultivate it. However, Gus Dur, the Indonesian president, stated in the media the goal to utilize any bare land, giving us courage to start planting on SFC's land. This was the only option to feed our families, who were suffering from the economic crisis. The SFC has not taken any action against our illegal activities until 2008, when the FVCO was formed in our village in a smooth process, and we were actually allowed to continue cultivating the forestland.' ( $\mathrm{I}_{44}$, translated by the author)

'Do you know why our people are still stealing timber from the forests? Because we are farmers-farming is all we can do-yet we do not have access to land because the SFC claims that it is their land. But our wives and kids need food. We are not afraid of being caught or shot by SFC officers. We are much more afraid that our families are starving to death.' ( $\mathrm{I}_{32}$, translated by the author)

It turned out that the general euphoria about democracy has encouraged landless farmers to act, and has sharpened the perception that the teak forests are owned by the state, not by the SFC. Thus, the SFC has "only" the mandate to manage them $\left(\mathrm{I}_{17}\right)$. Villagers who joined the grassroots forest users' group found a 'justification' to utilize these forests based on their needs and their own rules. The pro-community NGOs, i.e., international donors, promoted and backed up this movement, also providing the communities with access to needed information $\left(\mathrm{I}_{1} ; \mathrm{I}_{20} ; \mathrm{I}_{32} ; \mathrm{I}_{17} ; \mathrm{I}_{48}\right)$.

The SFC's interest in regaining its FSC certificate strengthened the bargaining position of grassroots forest farmers' groups. Their leaders were very well-informed about the SFC's situation, inter alia, by pro-community NGOs (including Arupa and Javlec). It was clear that the SFC needs to establish good relationships with communities and respect their tenure rights in order to regain its certificate $\left(\mathrm{I}_{17} ; \mathrm{I}_{29}\right)$.

The SFC took serious steps by issuing Standard Operating Procedures (SOP) for identifying, managing and peacefully settling conflicts with the communities $\left(\mathrm{I}_{9} ; \mathrm{I}_{56}\right)$. These SOP emphasized 
the need for a social approach and good communication relationships with the communities, to be achieved by regular involvement in social activities in the villages' working areas.

Overall, all the developments described above strengthened the communities' position vis-à-vis the SFC, and allowed them to further benefit from the state forests, even without necessarily following the prevailing rules as defined by the SFC $\left(\mathrm{I}_{29}\right)$. Table 1 summarizes the redistribution of resources due to the new program.

Table 1. Distribution of Collaborative Forest Management Program (CFMP) resources.

\begin{tabular}{clll}
\hline Aspect & \multicolumn{1}{c}{ Before CFMP } & $\begin{array}{c}\text { Provisions in CFMP } \\
\text { Regulation }\end{array}$ & \multicolumn{1}{c}{ Actual Practice } \\
\hline Financial benefits & $\begin{array}{l}\text { Farmers paid as laborers } \\
\text { for the State Forest } \\
\text { Company (SFC); no } \\
\text { financial benefit to other } \\
\text { villagers }\end{array}$ & $\begin{array}{l}\text { 25\% of timber benefit is } \\
\text { given to the villages } \\
\text { through the Forest } \\
\text { Village Community } \\
\text { Organization (FVCO) }\end{array}$ & $\begin{array}{l}\text { The SFC leads the } \\
\text { calculation process. } \\
\text { Monitoring undertaken } \\
\text { by pro-community } \\
\text { non-governmental } \\
\text { organizations (NGOs). }\end{array}$ \\
\hline \multirow{2}{*}{ Time } & $\begin{array}{l}\text { Collaboration for max. } 2 \\
\text { years; no written } \\
\text { agreement }\end{array}$ & $\begin{array}{l}\text { Flexible and longer } \\
\text { time-frame of written } \\
\text { collaboration agreement }\end{array}$ & $\begin{array}{l}\text { Farmers may cultivate } \\
\text { cash-crop plants of their } \\
\text { choice under the SFC's } \\
\text { trees for more than 2 } \\
\text { years }\end{array}$ \\
\hline Land & $\begin{array}{l}\text { Max. extent of } 0.25 \\
\text { hectares per person }\end{array}$ & $\begin{array}{l}\text { Can be discussed during } \\
\text { the planning stage of the } \\
\text { CFMP }\end{array}$ & $\begin{array}{l}\text { Opponents of the CFMP } \\
\text { may occupy more than } \\
\text { 0.25 hectares of land, } \\
\text { without sanction }\end{array}$ \\
\hline Cash crops species & Determined by the SFC & $\begin{array}{l}\text { Flexible based on } \\
\text { agreement }\end{array}$ & $\begin{array}{l}\text { Farmers can cultivate } \\
\text { any cash crop, including } \\
\text { banned ones, without } \\
\text { sanctions }\end{array}$ \\
\hline
\end{tabular}

In terms of the distribution of resources, in contrast to earlier community programs, the CFMP promotes a spirit of land-sharing-i.e., of utilizing state forestland, products and benefits. The summary in Table 1 shows that the potential for villagers to benefit from state forests is much higher and much more flexible in the new CFMP.

\subsection{Change in Dominant Discourses}

Before the decentralization and reformation era, the prevailing discourse was that the SFC manages state forests in Java successfully and sustainably, due to its highly qualified personnel, expertise and high capacities $\left(\mathrm{I}_{10} ; \mathrm{I}_{46} ; \mathrm{I}_{65}\right)$. Another discourse put forward by the SFC was that forest communities are the main actors behind timber thefts and illegal logging $\left(\mathrm{I}_{45} ; \mathrm{I}_{66}\right)$. These discourses prevailed for a long time, and were incorporated into governmental regulations, e.g., by safeguarding the SFC's dominant position. Likewise, these dominant discourses also discouraged district governments from becoming actively involved in the management of state forests until the decentralization era $\left(\mathrm{I}_{10} ; \mathrm{I}_{34}\right)$. This perception is illustrated by the following statement of a district representative:

'... for a very long time there has been a strong mind-set held by the district governments that forestry matters in their respective districts are to be taken care of only by the Central Government's bodies: The Ministry of Forestry and the State Forest Company in the case of Java.' ( $\mathrm{I}_{62}$ )

The development of the decentralization discourse, which gained momentum in the late 1990s in Indonesia and in Java in particular, cannot be isolated from coexisting discourses at the international, national and local levels; discourses concerning general reformation, land reform, agrarian reform and community-based natural resource management and good governance. 
The community forestry discourse was promoted by international and local NGOs and donor institutions. This discourse initially gained momentum at the World Forestry Congress 1978 in Jakarta, titled "Forests for People". However, it was not translated into national policies at that time. Before 1999, forests were perceived as a key resource for advancing economic growth. Consequently, the SFC focused on timber production, prioritizing industrial demand. Community forestry and welfare were not considered too relevant; empowering communities or even transferring authority were considered taboo in the Indonesian forestry bureaucracy at that time [66] (p. 8), [67].

In Java, NGOs significantly shaped the discourse on decentralization. While state actors mostly acted according to prevailing regulations, local NGOs, such as Arupa and Javlec, proactively developed and gave meaning to 'forest-related decentralization' by promoting (1) a more prominent role of district governments in state forest management and (2) community-based forest management for the benefit of local people $\left(\mathrm{I}_{1} ; \mathrm{I}_{20} ; \mathrm{I}_{48}\right)$. These NGOs advocated pushing back against the SFC's dominance $\left(\mathrm{I}_{1}\right.$; $\left.\mathrm{I}_{20} ; \mathrm{I}_{48}\right)$ to facilitate community access to state forests, e.g., by influencing the implementation of the SFC's CFMP.

The issuance of Law 41/1999 [68] has elevated the importance of the community's opportunities to derive benefits from state forests (Article 68 of Law 41/1999). At the same time, triggered by massive forest destruction, pressure from the public and markets, the suspension of its FSC certificate caused the SFC to change its vision and priority by including the aim of collaborating with forest communities, legalized through several Decrees of the SFC Board $[52,69,70]$. The ever-growing discourse and resulting pressures for more collaboration with local communities was finally also reflected in the CFMP in 2000 [71], e.g., by aiming to account for the social aspects of forest management. The following quote from a newspaper article written by several Indonesian forest scholars illustrates the general perception of what happened:

'In addition to the drive due to the reformation euphoria and a desire for 'revenge' in the community for the long-term centralistic management, illegal logging all over Java was further driven by the imbalanced market for [teak] timber production. The reformation movement had lit the flame of jealousy in the communities of the SFC forests [ ... ], blown out and manifest in continuous and massive illegal logging'. [10] (p. 31; translated by the author)

The CFMP was perceived by villagers as an improved version of earlier SFC programs, a response to the pressures described above $\left(\mathrm{I}_{6} ; \mathrm{I}_{48} ; \mathrm{I}_{65}\right)$. The situation in SFC's working areas nourished a discourse of blaming the SFC, arguing that the chaotic situation demonstrated its incapability to further manage these state forests properly in the traditional way [71].

At the time of its introduction, the reaction to and discourses about the CFMP were varied. The discourse in communities ranged from being very negative to being very positive about the idea of the CFMP. Some groups did not care at all, but the response depended heavily upon their interests in forest use (i.e., whether they were forest users or not). In general, at the start of CFMP implementation, the communities were broadly negative or suspicious about the program, mainly due to a lack of trust in the SFC, based on their previous experience with collaboration $\left(\mathrm{I}_{37} ; \mathrm{I}_{70}\right)$.

Some villagers, termed 'illegal loggers' by SFC representatives, worried that the CFMP would hamper their heretofore 'de facto' access to the state forests $\left(\mathrm{I}_{29} ; \mathrm{I}_{37}\right)$. Others, not being direct beneficiaries of the forests, were concerned about being suspected of working as informants of the SFC, especially by reporting illegal loggers. Some others, even some who were not users of the forests, however, perceived the CFMP as a window of opportunity that would enable them to get involved and benefit from state forest management $\left(\mathrm{I}_{23} ; \mathrm{I}_{39} ; \mathrm{I}_{53}\right)$.

The district legislative councils, DFAs and some researchers saw the CFMP as a win-win program $\left(\mathrm{I}_{3} ; \mathrm{I}_{10} ; \mathrm{I}_{34} ; \mathrm{I}_{54}\right)$, also showing the SFC's willingness to live up to the broadly-held euphoria about reformation by sharing with and involving local communities. Support of the provincial governments of Central Java was formalized in 2001 by provincial regulations, thus supporting the SFC's new 
CFMP, which was also promoted by strong lobbying from the SFC. Formalized provincial support was not provided in the West Java or East Java provinces $\left(\mathrm{I}_{6} ; \mathrm{I}_{21} ; \mathrm{I}_{63}\right)$. The general expectation was that following the provincial regulation, district authorities would actively support the implementation of the CFMP. However, the prevailing decentralization scheme did not oblige them to comply with provincial recommendations.

Another prominent discourse, carried mostly by NGOs and grassroots forest farmer organizations, portrayed the CFMP as an SFC strategy to merely secure its timber assets by employing community members as safeguards $\left(\mathrm{I}_{17} ; \mathrm{I}_{29} ; \mathrm{I}_{32} ; \mathrm{I}_{47} ; \mathrm{I}_{48}\right)$. Formal agreements in the CFMP scheme were perceived as mechanisms for regaining control over SFC working areas, not as an approach that would benefit communities $\left(\mathrm{I}_{29}\right)$. These conflicting ways of framing the CFMP still exist, and are regularly expressed in various media [12,72-76].

Finally, and less frequently expressed, we also found a rather neutral framing of the CFMP, expressed by forest policy experts and most researchers $\left(\mathrm{I}_{6} ; \mathrm{I}_{25} ; \mathrm{I}_{16} ; \mathrm{I}_{46} ; \mathrm{I}_{62}\right)$ and acknowledging CFMP as a win-win solution for the SFC and the communities. However, these individuals also noted that the benefit-sharing mechanism for the communities has not actually achieved its ultimate goal of increasing community welfare.

It is particularly interesting to note that the SFC institutionalized the notion of the CFMP, FSC certification and the issue of decentralization into its Vision and Mission. These "Vision" and "Mission" documents, legalized through several Decrees of the SFC Board $[52,69,70]$, are company internal regulations for implementation at the operational level.

Until the reformation era, by law, the SFC's objective was to undertake productive efforts in pursuit of governmental policies that sought to improve the national income by planting forests, maintaining and exploiting them, and marketing forest products [77]. Only in 1999 did the SFC update its vision 'to manage forest resources as an ecosystem in Java, by using fair, democratic, efficient and professional principles, to ensure their function and benefit for the welfare of the communities' [52]. In 2009 and 2014, an emphasis on the goals of sustainable forest management and local development was added [69,70]. Overall, we see a considerable change in the SFC's mission, despite its continued exclusivity - established in the regulation — as the most powerful actor shaping the direction of Java's forest governance. The three main challenges faced by the SFC, i.e., successfully addressing the decentralization policy and movement, implementing the CFMP and regaining FSC certification, have been considered the SFC strategic framework, which uses key words, such as forest community, sustainable forest management and local development.

Discourses during the decentralization movement revived the awareness that the SFC should not be acknowledged as a 'kingdom within a kingdom', i.e., it did not have exclusive authority over state forest management. Instead, the SFC was increasingly perceived as a company that has to respect the responsibilities and interests of district authorities and to acknowledge that many local villages and communities depend on forests for their livelihoods; thus, the SFC must share forest-derived benefits with those communities. Table 2 summarizes the main changes described above.

Table 2. Main changes by the Collaborative Forest Management Programme.

\begin{tabular}{|c|c|c|c|}
\hline Actors & Power and Resources & Rules & Discourses \\
\hline $\begin{array}{l}\text { - } \quad \begin{array}{l}\text { More actors' } \\
\text { involvement } \\
\text { and interactions }\end{array} \\
\text { - } \quad \begin{array}{l}\text { Increased influence of } \\
\text { actors other than SFC }\end{array} \\
\text { - Changed interaction } \\
\text { style of SFC }\end{array}$ & $\begin{array}{l}\text { Increased sharing of } \\
\text { timber benefits } \\
\text { to communities } \\
\text { From pure top-down to } \\
\text { increased negotiation } \\
\text { power of communities }\end{array}$ & $\begin{array}{l}\text { - New community } \\
\text { empowerment and } \\
\text { benefit-sharing scheme } \\
\text { Stronger } \\
\text { institutionalization and } \\
\text { formal agreement of } \\
\text { community involvement }\end{array}$ & $\begin{array}{l}\text { Diverse perceptions of } \\
\text { CFMP by } \\
\text { different actors } \\
\text { Discourse on SFM and } \\
\text { nation-wide } \\
\text { reformation translated } \\
\text { into SFC's forest } \\
\text { management } \\
\text { framework \& policy }\end{array}$ \\
\hline
\end{tabular}




\section{Discussion: Synthesizing the Changes across Analytical Dimensions}

\subsection{Formalization of Inclusive CFMP Governance}

The issuance of the first national decentralization law in 1999 laid down the legal framework for the promulgation of various sector-based regulations at the national, provincial and district levels $[57,68,78-80]$. Rapid changes in the development of the regulatory framework of Java's forest governance at the national, provincial and district levels have taken place since 1999. However, there was no legal imperative for the SFC to establish a new and significantly more inclusive community forestry program.

Nevertheless, due to the pressure caused by the reformation movement in various ways, the SFC finally introduced and formalized the CFMP, including a new benefit-sharing scheme comprising a much wider range of beneficiaries compared to former programs. To stabilize a chaotic situation induced by the enthusiasm for reformation, the SFC was-ultimately and importantly-urged to gain the support of the communities to prevent massive illegal logging and all its negative consequences.

The SFC regulation on the CFMP marked significant changes in the governance of the SFC's community program, laying down rules for governing actor interactions and determining the distribution of resources and benefits [52]. However, this is an internal SFC policy only; thus, from a formal perspective, the company can change it again at its own discretion. Nevertheless, as our analysis shows, such a move might entail substantial problems and high costs for the SFC.

Through the CFMP, a collaboration arrangement between the SFC and the communities was formalized, changing from an informal agreement to a contract. The grassroots farmer group (non-FVCO members) and their rights to utilize state forests were also formally acknowledged by the SFC. Overall, the communities benefited from a much more secure scheme for collaboration with the SFC.

\subsection{Strengthened Role of Informal Rules and Local Actors}

Our analysis shows that informal rules have played a significant role by backing and motivating the communities' actions in pushing for changes in the community forest program with regard to inclusiveness and benefit sharing. Customary practices, local norms and beliefs were at work, often at the margins or even beyond the legal framework as defined by state regulations (for similar findings for Vietnam, South Africa, Latin America and India see [81-84]).

In both districts, communities organized themselves in grassroots farmer groups, and gained tolerated access beyond what was formally prescribed by the SFC. In the Kendal district, a grassroots group utilized state forests according to their own rules, first in conflict with formal rules, but later in formal agreement with the SFC in certain parts of state forest areas. Instead of taking top-down measures to halt the illegal practices-as would have happened in former years-the SFC strived for a formalized agreement with the grassroots farmers' group, finally providing some freedom to the farmers in their use of state forests, but also acknowledging the formal authority of the SFC.

While informal rules became tolerated and formalized through a relatively smooth process in Kendal, the development in the Blora district was much more conflictual. The different paths taken towards the formalization of informal rules in the two districts can be explained by two factors: some difference in historical background, and the existence of a strong pro-community NGO (Arupa) in this Blora district.

\subsection{Redistribution of Power and Resources}

The redistribution of resources among actors was triggered by a combination of developing discourses and the increased role of informal rules; it was also advanced by non-state actors involved in the implementation of decentralization. Later, the change in SFC policy further contributed to the redistribution. The increased role of NGOs and the revival of a grassroots movement strengthened communities in terms of expertise, negotiation skills and power; the communities' knowledge about 
"where, when, how and by whom" illegal logging was taking place was also essential to the SFC. Furthermore, communities' willingness to cooperate with the DFA was necessary to legitimate the CFMP proposal of the SFC, and the communities' goodwill was also needed by the SFC to regain FSC certification. This situation made the SFC dependent upon local communities and the DFA, as also confirmed by Maryudi et al. for the case of Kendal District [85] (p. 74).

However, in the new CFMP scheme, communities-particularly landless community members-are still dependent on the SFC if they want to obtain additional benefits from timber production. The SFC still holds formal authority over state forest areas, and has the information and skills to calculate respective community shares of timber benefits. Finally, from a purely formal point of view, the SFC can change its internal CFMP rules at its own discretion.

Practically, however, the power balance has changed in favor of the communities, from the one-way, top-down mode to a much more negotiated relationship. The redistribution of power and resources in the CFMP took place at both research sites, as also found by Rosyadi [86] (p. 29).

\subsection{Institutionalization of Discourses}

This study shows that shifts in discourses became institutionalized in Java's community forest governance and management program. Ideas of changing a hierarchical state-centered system into a more community-oriented collaborative management system were institutionalized by a change in SFC policy, followed by the formation of FVCOs, formal agreements between the SFC and the forest farmer groups, and financial arrangements for timber-benefit sharing. Furthermore, the national-level discourse and the international discourse on sustainable development and community involvement have been institutionalized in the SFC's vision and mission since $2000[52,69,70]$, emphasizing the importance of forest communities and local development. The process towards institutionalization was strongly influenced through and pushed forward by a pro-community NGO in the district of Blora. Nevertheless, the grassroots movement in Kendal district also succeeded in achieving institutionalization, even without the support of such a local NGO.

\subsection{Changing Patterns of Actors' Interactions and Perceptions}

In line with the findings above, our analysis documents changes in the interactions between the SFC and communities in both research districts, from a top-down, sometimes even military style to a more relaxed and informal one [87]. The change in relationship led to greater appreciation of the ecological functions of forests and of the role of the SFC in allowing and enabling the communities to take care of them (ibid.). The new negotiated relationship indicates the foresters' declining monopoly over state forest management. Peluso [88] (p. 826) also argues that while on the surface, the SFC retained its authority over Java's forests, there is no longer an SFC monopoly over the production of certain forest products and species.

While our study confirms these findings of other scholars, we bestow new insights into the factors that contribute to the changes in interactions:

1. The new mode of the CFMP pushed SFC personnel to maintain good communication with the communities to smooth the process of establishing FVCOs, which were required for implementing the CFMP. From 2000 to 2005, the number of established FVCOs was a performance indicator of the SFC.

2. The cancellation of the SFC's timber certification urged the SFC to apply a 'drop the gun policy', and to establish cooperative approaches towards communities.

3. The revival of the grassroots movement has shown that mass mobilization, also resulting in massive illegal logging, can be a very powerful weapon against formal authority. To minimize any further destruction of forest resources, the SFC had no option but to reconsider its interactions with local communities. 
Furthermore, we see significant changes in the local actors' perceptions concerning the actors who should be involved in forest governance. District governments have become more interested in forest governance, although with different intensities in the two districts that we researched. Previously, the SFC was assumed to be the most capable, or even only institution capable, of managing Java's state forests. It was also assumed that district governments have no role in the SFC's forest management $\left(\mathrm{I}_{10} ; \mathrm{I}_{46} ; \mathrm{I}_{62} ; \mathrm{I}_{65}\right)$. In the wake of the decentralization debate, this perspective has changed, and it is now emphasized that district governments should play a role, because the SFC alone is incapable of managing the state forests $\left(\mathrm{I}_{1} ; \mathrm{I}_{20} ; \mathrm{I}_{48}\right)$. Accordingly, both DFAs decided to intervene, and strengthened their position vis-à-vis central state authorities in general, and the SFC in particular.

Because the SFC had to acknowledge that Java's state forests could no longer be managed independently (see above), it welcomed the district governments that were taking responsibility for the welfare of forest communities.

Indeed, the SFC was criticized for failing to improve the communities' livelihoods through its various community-involvement programs introduced since the 1970s $[44,89,90]$. Peluso (1992) characterized the contrast between the SFC-managed teak forests and the situation in nearby villages concisely with her book title 'rich forest poor people' [44]. The lack of interaction between forest communities and the district governments was also due to the exclusionary management style of the SFC in its community-involvement programs prior to 2000. These programs limited interactions to those between the SFC and the forest users only.

\section{Summary and Conclusions}

In the late 1990s, Indonesia's governance system underwent dramatic changes due to a national decentralization policy following the national reformation movement. Our research is inspired by the general perception in Indonesia and among scholars that, unlike in the context of the Outer Islands, the decentralization policy and movement era has not significantly influenced forest governance in Java, due to a legally-sustained monopoly of the State Forest Company (SFC). Accordingly, forest-related decentralization research in Indonesia focused very much on the Outer Islands. Despite a few studies on Java Island, which indicated some changes (see above), there is arguably a widely shared view that the dominance of the SFC indeed continues, largely unaffected by the overall reforms. However, our study shows that due to decentralization, significant changes have taken place in the SFC's community forestry program (CFMP), e.g., in terms of much greater inclusiveness, communities' access and the benefits that communities can now derive from state forests.

Although the basic ideas underlying the CFMP are not entirely new, its introduction marks a change in the way the SFC interacts with communities and with local and national authorities. Since the program's launch in 2001, it has developed quite successfully. According to the Annual Report of the SFC 2019, more than 2.2 million ha (5.4 mio. acres, or 8,494 square miles) of Java's state forest area are operated under the CFMP scheme, based upon more than five thousand collaboration agreements between more than five thousand village organizations and the SFC [91]. This area represents more than 90 percent of the SFC's total forest area on Java Island.

In light of the decentralization, the CFMP has raised the awareness of local authorities concerning their rights, roles and potential power to influence decision making concerning the management of state forest areas in their jurisdiction. For some empowered local institutions, the CFMP became an arena and 'ready-to-use channel', enabling them to benefit from their powers and resources.

The fact that CFMP was launched during the initiation of the decentralization and reformation era plausibly indicates that its establishment in the new mode is connected to the decentralization policy and movement. Our research digs deeper. It reveals factors and processes resulting from or furthered by decentralization policies and discourses, which led to the specific form of the new CFMP, factors beyond the mere temporal concurrence with national decentralization reforms. The CFMP serves as a powerful instrument for implementing decentralization, including democratization, by improving 
the accountability and inclusiveness of provincial, district and village governments (for a nationwide perspective, see [24]).

We argue that the few changes in formal regulations resulting from the national decentralization policy as such, are not the predominant cause of these changes in CFMP governance and practices. These changes did not mainly take place as a result of the authority given to district governments by the new regulations. District-level authorities and other local actors did not necessarily embrace these new opportunities at first. However, the interplay of various, partly mutually reinforcing, factors has, step by step, finally led to significant changes. The decentralization policy and movement has fueled these changes in various ways: (a) By promoting global- and national-level discourses on sustainable forest management, community forestry and local development at the regional and local levels; (b) by catalyzing the revival of grassroots movements and long-held traditional beliefs and habits of local communities concerning their use of forests; (c) by inspiring local claims for participation and more transparent information, triggering the formal institutionalization of societal norms, informal rules and practices of local communities; and (d) by urging state actors to reconsider their roles and goals in Java's forest management. Pro-community NGOs are identified as important agents of these changes by empowering forest communities to represent their interests successfully, take responsibility, and demonstrate their capacities to manage forest resources.

In summary, regarding our particular case, we conclude that the impact of the reformation movement, such as the decentralization movement and policies studied here, cannot be determined on the basis of changes in formal regulations. There is much to consider.

Even with all of the changes induced by the decentralization policy and movement, the SFC formally and practically remains the central forest governance actor in Java, but it is no longer virtually the only actor. At the time of the fieldwork for this paper, the CFMP has remained a 'collaboration-based', but not a 'community-based', forest management program. However, it was much more strongly affected by the nationwide decentralization movement than one would have expected. Change occurred despite a strong foundation of the central power of the state forest enterprise (SFC) due to a long-term state-centered and rigid forest governance arrangement, as inherited from colonial times. Moreover, unlike the social forestry scheme, as practiced in the Outer Islands, the CFMP introduced a timber-based profit-sharing scheme for the first time [92].

What remains unanswered are the questions of whether and to what extent the seemingly positive changes will be sustained.

Author Contributions: The authors contributed equally to the conceptualization of the research design, the methodology, the preparation of empirical investigations, the interpretation of data, and to the writing of manuscripts for this paper. The collection of primary data in the field, data curation and the formal analysis of interview transcripts was done by W.A., supervised by K.H. The final review and editing of the manuscript was primarily conducted by K.H., also the revision based on the constructive feedback by W.A. and K.H.

Funding: The first field trip for explorative empirical research was supported by a KUWI scholarship for short-term scientific work abroad awarded directly by the University of Natural Resources and Life Sciences Vienna. The open access publishing was supported by BOKU Vienna Open Access Publishing Fund.

Conflicts of Interest: The authors declare no conflict of interest.

\section{Appendix A}

Table A1. List of Informants' Affiliation and Location of Interviews.

\begin{tabular}{ccc}
\hline Reference & Affiliations & Interview Location (City, Town) \\
\hline $\mathrm{I}_{1}$ & Non-Government Organization & Yogyakarta \\
$\mathrm{I}_{2}$ & State Forest Company & Jakarta \\
$\mathrm{I}_{3}$ & District Legislative Council & Blora \\
$\mathrm{I}_{4}$ & State Forest Company & Kendal \\
$\mathrm{I}_{5}$ & Scientist & Bogor \\
\hline
\end{tabular}


Table A1. Cont.

\begin{tabular}{|c|c|c|}
\hline Reference & Affiliations & Interview Location (City, Town) \\
\hline $\mathrm{I}_{6}$ & Academia and scientist & Yogyakarta \\
\hline $\mathrm{I}_{7}$ & State Forest Company & Kendal \\
\hline $\mathrm{I}_{8}$ & Ministry of Forestry & Jakarta \\
\hline $\mathrm{I}_{9}$ & State Forest Company & Jakarta \\
\hline $\mathrm{I}_{10}$ & District Forest Authority & Kendal \\
\hline $\mathrm{I}_{11}$ & State Forest Company & Kendal \\
\hline $\mathrm{I}_{12}$ & District Forest Authority & Kendal \\
\hline $\mathrm{I}_{13}$ & Academia & Bogor \\
\hline $\mathrm{I}_{14}$ & Scientist & Bogor \\
\hline $\mathrm{I}_{15}$ & State Forest Company & Kendal \\
\hline $\mathrm{I}_{16}$ & Non-Government Organization & Bogor \\
\hline $\mathrm{I}_{17}$ & Community/Grass-Root Forest Farmer Group & Kendal \\
\hline $\mathrm{I}_{18}$ & Forest Policy Expert & Bogor \\
\hline $\mathrm{I}_{19}$ & District Forest Authority & Kendal \\
\hline $\mathrm{I}_{20}$ & Non-Government Organization & Yogyakarta \\
\hline $\mathrm{I}_{21}$ & Forest Policy Expert & Bogor \\
\hline $\mathrm{I}_{22}$ & Non-Government Organization & Blora \\
\hline $\mathrm{I}_{23}$ & Forest Community/FVCO & Kendal \\
\hline $\mathrm{I}_{24}$ & Non-Government Organization & Semarang \\
\hline $\mathrm{I}_{25}$ & Scientist & Jakarta \\
\hline $\mathrm{I}_{26}$ & State Forest Company & Semarang \\
\hline $\mathrm{I}_{27}$ & District Legislative Council & Kendal \\
\hline $\mathrm{I}_{28}$ & Community & Blora \\
\hline $\mathrm{I}_{29}$ & Community/Grass-Root Forest Farmer Group & Kendal \\
\hline $\mathrm{I}_{30}$ & PF Owner/People's Forest Farmer Group & Kendal \\
\hline $\mathrm{I}_{31}$ & Community & Blora \\
\hline $\mathrm{I}_{32}$ & Community/Grass-Root Forest Farmer Group & Blora \\
\hline $\mathrm{I}_{33}$ & District Legislative Council & Blora \\
\hline $\mathrm{I}_{34}$ & District Forest Authority & Blora \\
\hline $\mathrm{I}_{35}$ & Non-Government Organization & Bogor \\
\hline $\mathrm{I}_{36}$ & Community/Village Head & Kendal \\
\hline $\mathrm{I}_{37}$ & Forest Community/FVCO & Blora \\
\hline $\mathrm{I}_{38}$ & PF Owner & Kendal \\
\hline $\mathrm{I}_{39}$ & Forest Community/Village Head & Blora \\
\hline $\mathrm{I}_{40}$ & State Forest Company & Blora \\
\hline $\mathrm{I}_{41}$ & Regional Development Agency & Kendal \\
\hline $\mathrm{I}_{42}$ & PF Owner & Kendal \\
\hline $\mathrm{I}_{43}$ & District Forest Authority & Blora \\
\hline $\mathrm{I}_{44}$ & Forest Community/FVCO & Kendal \\
\hline $\mathrm{I}_{45}$ & Provincial Forest Authority & Semarang \\
\hline $\mathrm{I}_{46}$ & Academia and scientist & Yogyakarta \\
\hline $\mathrm{I}_{47}$ & Community/Grass-Root Forest Farmer Group & Kendal \\
\hline $\mathrm{I}_{48}$ & Non-Government Organization & Yogyakarta \\
\hline $\mathrm{I}_{49}$ & Forest Policy Expert & Yogyakarta \\
\hline $\mathrm{I}_{50}$ & Provincial Forest Authority & Semarang \\
\hline $\mathrm{I}_{51}$ & Community/People's Forest Farmer Group & Blora \\
\hline $\mathrm{I}_{52}$ & Community/People's Forest Farmer Group & Blora \\
\hline $\mathrm{I}_{53}$ & Community/FVCO & Blora \\
\hline $\mathrm{I}_{54}$ & District Forest Authority & Kendal \\
\hline $\mathrm{I}_{55}$ & Community/FVCO & Kendal \\
\hline $\mathrm{I}_{56}$ & State Forest Company & Kendal \\
\hline $\mathrm{I}_{57}$ & State Forest Company & Kendal \\
\hline $\mathrm{I}_{58}$ & District Forest Authority & Kendal \\
\hline $\mathrm{I}_{59}$ & Community/People's Forest Farmer Group & Kendal \\
\hline $\mathrm{I}_{60}$ & Community/FVCO & Kendal \\
\hline
\end{tabular}


Table A1. Cont.

\begin{tabular}{ccc}
\hline Reference & Affiliations & Interview Location (City, Town) \\
\hline $\mathrm{I}_{61}$ & State Forest Company & Semarang \\
$\mathrm{I}_{62}$ & Academia and scientist & Yogyakarta \\
$\mathrm{I}_{63}$ & State Forest Company & Blora \\
$\mathrm{I}_{64}$ & Ministry of Forestry & Jakarta \\
$\mathrm{I}_{65}$ & Academia and scientist & Yogyakarta \\
$\mathrm{I}_{66}$ & Forest Policy Expert/SFC & Yogyakarta \\
$\mathrm{I}_{67}$ & State Forest Company & Blora \\
$\mathrm{I}_{68}$ & Community/FVCO & Kendal \\
$\mathrm{I}_{69}$ & Provincial Forest Authority & Semarang \\
$\mathrm{I}_{70}$ & Community/FVCO/Village Head & Blora \\
$\mathrm{I}_{71}$ & Academia and scientist & Bogor \\
$\mathrm{I}_{72}$ & State Forest Company & Jakarta \\
$\mathrm{I}_{73}$ & Ministry of Forestry & Jakarta \\
\hline
\end{tabular}

\section{References}

1. Agrawal, A.; Chhatre, A.; Hardin, R. Changing governance of the world's forest. Science 2008, 320, 1460-1462. [CrossRef] [PubMed]

2. Andersson, K. Understanding decentralised forest governance: An application of the institutional analysis and development framework. Sustain. Sci. Pract. Policy 2006, 2, 25-35.

3. Leon, R.; Uberhuaga, P.; Benavides, J.P.; Andersson, K. Public policy reforms and indigenous forest governance: The case of the Yuracare people in Bolivia. Conserv. Soc. 2012, 10, 195-207.

4. Larson, A.M.; Soto, F. Decentralization of natural resource governance regimes. Annu. Rev. Env. Resour. 2008, 33, 213-239. [CrossRef]

5. Lund, J.F.; Rutt, R.L.; Ribot, J.C. Trends in research on forestry decentralization policies. Curr. Opin. Environ. Sustain. 2018, 32, 17-22. [CrossRef]

6. Republic of Indonesia. The Law of the Republic of Indonesia No. 22 Year 1999 Concerning Regional Administration; Republic of Indonesia: Jakarta, Indonesia, 1999.

7. Rosyadi, S.; Birner, R.; Zeller, M. Creating political capital to promote devolution in the forestry sector-A case study of the forest communities in Banyumas district, Central Java, Indonesia. Policy Econ. 2005, 7, 213-226. [CrossRef]

8. Nomura, K. The politics of participation in forest management: A case from democratizing Indonesia. J. Environ. Dev. 2008, 17, 166-191. [CrossRef]

9. Kedaulatan Rakyat. Penjarahan Hutan Marak Di Mana-Mana: Ekonomi Rakyat Terpuruk, Hutan Disikat. Kedaulatan Rakyat, 24 June 2000; p. 4.

10. Kompas. Pulau Tropika Jawa Riwayatmu. Kompas, 9 February 2003; p. 31.

11. Suara Merdeka. Fasilitas Perhutani Dirusak Massa, Dipicu Seorang Pencuri Kayu Tewas. Suara Merdeka, 15 June 2006; p. 1.

12. Pengelolaan Hutan di Jawa oleh Perhutani Dinilai Gagal Sejahterakan Masyarakat. Mongabay Online News. 2013. Available online: https://www.mongabay.co.id/2013/01/28/pegelolaan-hutan-di-jawa-oleh-perhutanidinilai-gagal-sejahterakan-masyarakat/ (accessed on 27 June 2019).

13. Subadi. Desentralisasi Penguasaan dan Pendayagunaan Tanah di Kawasan Hutan Jawa: Antara Harapan dan Kenyataan. J. Mimb. Huk. Fak. Huk. Univ. Gadjah Mada 2011, 23, 132-149.

14. Kolopaking, L.M.; Turasih. Proses-Proses Kebijakan dan Penguatan Kelembagaan Hutan Kayu Rakyat pada Era Desentralisasi di Jawa; Working Paper; PSP3-IPB: Bogor, Indonesia, 2013.

15. Sudirman; Wiliam, D.; Herlina, N. Local Policy-making Mechanisms: Processes, Implementation and Impacts of the Decentalized Forest Management System in Tanjung Jabung Barat District, Jambi; CIFOR: Bogor, Indonesia, 2005.

16. Wollenberg, E.; Moeliono, M.; Limberg, G.; Iwan, R.; Rhee, S.; Sudana, M. Between state and society: Local governance of forests in Malinau, Indonesia. Policy Econ. 2006, 8, 421-433. [CrossRef]

17. Moeliono, M.; Wollenberg, E.; Limberg, G. The Decentralization of Forest Governance: Politics, Economics and the Fight for Control of Forests in Indonesian Borneo; Earthscan: London, UK, 2009. 
18. Yasmi, Y.; Guernier, J.; Colfer, C.J.P. Positive and negative aspects of forestry conflict: Lessons from a decentralised forest management in Indonesia. Int. Rev. 2009, 11, 98-110. [CrossRef]

19. Bullinger, C.; Haug, M. In and out of the forest: Decentralisation and recentralisation of forest governance in East Kalimantan, Indonesia. ASEAS Austrian J. South-East Asian Stud. 2012, 5, 243-262.

20. Tolo, E.Y.S. Public Participation in the Implementation of Forestry Decentralization in Indonesia. Int. J. Adm. Sci. Organ. 2013, 20, 113-120.

21. Bae, J.S.; Kim, Y.S.; Fisher, L.; Moeliono, M.; DeShazo, J. Promises and perils of decentralized forest governance: The case of Indonesia's forest management units in reducing emission from deforestation and forest degradation (REDD+). Soc. Nat. Resour. 2014, 27, 1346-1354. [CrossRef]

22. Suwarno, A.; Hein, L.; Sumarga, E. Governance, decentralization and deforestation: The case of Central Kalimantan Province, Indonesia. Q. J. Int. Agric. 2015, 54, 77-100.

23. Fatem, M.S.; Awang, S.A.; Pudyatmoko, S.; Sahide, M.A.K.; Pratama, A.A.; Maryudi, A. Camouflaging economic development agendas with forest conservation narratives: A strategy of lower governments for gaining authority in the re-centralising Indonesia. Land Use Policy 2018, 78, 699-710. [CrossRef]

24. Thung, P.H. Decentralization of Government and Forestry in Indonesia; CIFOR Working Paper 249; CIFOR: Bogor, Indonesia, 2019.

25. Jann, W.; Wegrich, K. Phasenmodelle und politikprozesse: Der policy cycle. In Lehrbuch der Politikfeldanalyze; Schubert, K., Bandelow, N.C., Eds.; R Oldenbourg Verlag: Munich, Germany, 2003; pp. 71-104.

26. Arts, B.; van Tatenhove, J. Policy and power: A conceptual framework between the "old" and the "new" policy idioms. Policy Sci. 2004, 37, 339-356. [CrossRef]

27. Arts, B.; van Tatenhove, J.; Leroy, P. Policy arrangements. In Political Modernisation and the Environment: The Renewal of Environmental Policy Arrangements; van Tatenhove, J., Arts, B., Leroy, P., Eds.; Springer: Dordrecht, The Netherlands, 2000; pp. 53-69.

28. Veenman, S.; Liefferink, D.; Arts, B. A short history of Dutch forest policy: The 'de-institutionalisation' of a policy arrangement. Policy Econ. 2009, 11, 202-208. [CrossRef]

29. Arts, B.; Buizer, M. Forest, discourses, institutions: A discursive-institutional analysis of global forest governance. Policy Econ. 2009, 11, 340-347. [CrossRef]

30. Beeko, C.; Arts, B. The EU-Ghana VPA: A comprehensive policy analysis of its design. Int. Rev. 2010, 12, 221-230. [CrossRef]

31. Ahebwa, W.M.; Van der Duim, V.R.; Sandbrook, C. Tourism revenue sharing policy at Bwindi impenetrable national park, Uganda: A policy arrangements approach. J. Sustain. Tour. 2012, 20, 377-394. [CrossRef]

32. Ayana, A.N.; Arts, B.; Wiersum, K.F. Historical development of forest policy in Ethiopia: Trends of institutionalization and deinstitutionalization. Land Use Policy 2013, 32, 186-196. [CrossRef]

33. Lamers, M.; Van der Duim, R.; van Wijk, J.; Nthiga, R.; Visseren-Hamakers, I.J. Governing conservation tourism partnerships in Kenya. Ann. Tour. Res. 2014, 48, 250-265. [CrossRef]

34. Park, M.S.; Youn, Y. Development of urban forest policy-making toward governance in the Republic of Korea. Urban For. Urban Green. 2013, 12, 273-281. [CrossRef]

35. Dang, T.K.P.; Visseren-Hamakers, I.J.; Arts, B. Forest devolution in Vietnam: From rhetoric to performance. Land Use Policy 2018, 77, 760-774. [CrossRef]

36. Dang, T.K.P.; Van Der Zouwen, M.; Arts, B. Challenges of forest governance: The case of forest rehabilitation in Vietnam. Public Organiz. Rev. 2018, 1-28. [CrossRef]

37. Buizer, M. Worlds apart: Interactions between Local Initiatives and Established Policy. Ph.D. Dissertation, Wageningen University, Wageningen, The Netherlands, 2008.

38. Liefferink, D. The dynamics of policy arrangements: Turning round the tetrahedron. In Institutional Dynamis in Environmental Governance; Arts, B., Leroy, P., Eds.; Springer: Dordrecht, The Netherlands, 2006; pp. 45-68.

39. Wiering, M.A.; Arts, B.J.M. Discursive Shift in Dutch River Management: 'Deep' Institutional Change or Adaptation Strategy? Hydrobiologia 2006, 565, 327-338. [CrossRef]

40. Scharpf, F.W. Games Real Actors Play. Actor-Centered Institutionalism in Policy Research; Westview Press: Boulder, CO, USA, 1997.

41. Badan Pusat Statistik [BPS] Kendal. Kabupaten Kendal Dalam Angka 2015. Available online: https://kendalkab. bps.go.id/publication/2015/10/12/e2eb6eae8835eb34a459a177/kabupaten-kendal-dalam-angka-2015.html (accessed on 27 June 2019). 
42. Badan Pusat Statistik [BPS] Blora. Kabupaten Blora dalam Angka 2015. Available online: https://blorakab.bps. go.id/publication/2015/11/02/5654e6a2f74544a5c12522c0/kabupaten-blora-dalam-angka-2015.html (accessed on 27 June 2019).

43. Ribot, J.C.; Agrawal, A.; Larson, A.M. Recentralizing while decentralising: How national governments reappropriate forest resources. World Dev. 2006, 34, 1864-1886. [CrossRef]

44. Peluso, N.L. Rich Forests, Poor People: Resource Control and Resistance in Java; University of California Press: Oakland, CA, USA, 1992.

45. Large, J.P. Making the Links between Natural Resource Policy and Livelihood Dynamics of the Rural Poor: Social Forestry in Java, Indonesia; Working Paper No. 19; International Development Research Centre (IDRC): Ottawa, ON, Canada, 2005.

46. Nurjaya, I.N. Sejarah hukum pengelolaan hutan di Indonesia. Jurisprudence 2005, 2, 35-55.

47. Diantoro, T.D. Quo vadis hutan Jawa. In Wacana, Rekonfigurasi Pengelolaan Hutan Jawa; Insist Press: Yogyakarta, Indonesia, 2011; pp. 5-25.

48. Adi, N.J.; Arganata, F.; Chehafudin, M.; Fuad, F.H.; Nugraheni, S.C.A.; Sanyoto, R.; Soriaga, R.; Walpole, P. Community Transforming Forestland: Java, Indonesia; Asia Forest Network: Manila, Philippines, 2004.

49. Peluso, N.L. Traditions of forest controling Java: Implications for social forestry and sustainability. Nat. Resour. J. 1992, 32, 883-918.

50. Peluso, N.L.; Poffenberger, M. Social forestry in Java: Reorienting management systems. Hum. Organ. 1989, 48, 333-344. [CrossRef]

51. Arts, B.; de Koning, J. Community forest management: An assessment and explanation of its performance through QCA. World Dev. 2017, 96, 315-325. [CrossRef]

52. Republic of Indonesia. Decree of the SFC's Board of Directors No. 136/KPTS/DIR/2001 concerning the Collaborative Forest Management Programme; Republic of Indonesia: Jakarta, Indonesia, 2001.

53. Republic of Indonesia. Decree of the SFC's Board of Directors No. 001/KPTS/DIR/2002 concerning Guidance for Sharing of Timber Benefit; Republic of Indonesia: Jakarta, Indonesia, 2002.

54. Republic of Indonesia. Decree of the SFC's Board of Directors No. 268/KPTS/DIR/2007 concerning the Collaborative Forest Management Programme Plus; Republic of Indonesia: Jakarta, Indonesia, 2007.

55. Republic of Indonesia. Decree of the SFC's Board of Direction No. 682/KPTS/DIR/2009 concerning the Collaborative Forest Management Programme; Republic of Indonesia: Jakarta, Indonesia, 2009.

56. Republic of Indonesia. Decree of the SFC's Board of Direction No. 436/KPTS/DIR/2011 concerning Revised Guidance for Sharing of Timber Benefit; Republic of Indonesia: Jakarta, Indonesia, 2011.

57. Republic of Indonesia. Governor of Central Java Decree No. 24/2001 concerning the Collaborative Forest Management Programme in Central Java Province; Republic of Indonesia: Jakarta, Indonesia, 2001.

58. Blora District Forest Authority. Laporan Kinerja Instansi Pemerintah Dinas Kehutanan Kabupaten Blora Tahun 2015; Dinas Kehutanan Kabupaten Blora: Blora, Indonesia, 2015.

59. Central Java Provincial Forest Authority. Laporan Gabungan Realisasi Penerimaan Iuran Kehutanan; Central Java Provincial Authority: Semarang, Indonesia, 2015.

60. Andiko. Menempa Ingin Menjaga Percikan Api: Tantangan Gerakan Petani Hutan di Jawa; Hu-Ma: Jakarta, Indonesia, 2006.

61. Wulan, Y.; Yasmi, Y.; Purba, C.; Wollenberg, E. Analisa Konflik Sektor Kehutanan di Indonesia 1997-2003; CIFOR: Bogor, Indonesia, 2004.

62. Bakhtiar, I. Desa Mengepung Hutan; Lembaga Arupa: Yogyakarta, Indonesia, 2000; Available online: http://arupa.or.id/sources/uploads/2012/04/Buku-Desa-Mengepung-Hutan.pdf (accessed on 27 June 2019).

63. Bakhtiar, I. Hutan Jawa Menjemput Ajal; Lembaga Arupa: Yogyakarta, Indonesia, 2001.

64. Astraatmaja, R.; Fuad, F.; Ginting, L.; Loraas, K.T. The certification and de-certification of Perum Perhutani. Case study 3. In Trading in Credibility: The Myth and Reality of the Forest Stewardship Council; Counsell, S., Loraas, K., Eds.; Rainforest Foundation: London, UK, 2002; pp. 72-85.

65. Inoguchi, A.; Soriaga, R.; Walpole, P. Approaches to Controlling Illegal Forest Activities: Considerations from Southeast Asia; Working Paper Series No. 7; Asia Forest Network: Bohol, Philippines, 2005.

66. Santoso, H. Forest Area Rationalization in Indonesia: A Study on The Forest Resource Condition and Policy Reform; World Agroforestry Centre (ICRAF): Bogor, Indonesia, 2003.

67. Thorburn, C.C. The plot thickens: Land administration and policy in post-New Order Indonesia. Asia Pac. Viewp. 2004, 45, 33-49. [CrossRef] 
68. Republic of Indonesia. The Law of the Republic of Indonesia No. 41 Year 1999 Concerning Forestry; Republic of Indonesia: Jakarta, Indonesia, 1999.

69. Republic of Indonesia. Decree of SFC's Board of Direction: No. 17/Kpts/Dir/2009 Concerning Vision and Mission of the State Forest Company; Republic of Indonesia: Jakarta, Indonesia, 2009.

70. Republic of Indonesia. Decree of SFC's Board of Direction: No. 3180/Kpts/Dir/2014 Concerning Vision and Mission of the State Forest Company; Republic of Indonesia: Jakarta, Indonesia, 2014.

71. Sulastriyono; Hanif, H.; Manalu, D.; Purwanto, A.B. Hutan Jawa Layak Dikelola Rakyat. In Hutan Jawa: Kontestasi dan Kolaborasi; Suprapto, E., Purwanto, A.B., Eds.; BP Arupa: Yogyakarta, Indonesia, 2013; pp. 117-214.

72. Melalui PHBM, LMDH Wono Lestari Burno, Minimal Hasilkan Rp. 4,6 Milyar Setahun. JatimTimesNews. 2017. Available online: https://jatimtimes.com/baca/160685/20171025/125145/melalui-phbm-lmdh-wonolestari-burno-minimal-hasilkan-rp-46-milyar-setahun/ (accessed on 27 June 2019).

73. Hadang Truk, Perhutani Gagalkan Pencurian Kayu Jati. Kompas Online News. 2018. Available online: https://regional.kompas.com/read/2018/01/26/14421451/hadang-truk-perhutani-gagalkan-pencuriankayu-jati (accessed on 27 June 2019).

74. Perhutanan Sosial Dorong Reforestasi, Bukan Legalisasi Deforestasi. Mongabay News. 2018. Available online: https://www.mongabay.co.id/2018/07/30/perhutanan-sosial-dorong-reforestasi-bukan-legalisasideforestasi/ (accessed on 27 June 2019).

75. Lahan Bekas Tebangan Dihijaukan Kembali. Pikiran Rakyat Online News. 2016. Available online: https://www.pikiran-rakyat.com/jawa-barat/2016/11/10/lahan-bekas-tebangan-dihijaukan-kembali384366 (accessed on 27 June 2019).

76. 29 LMDH Terima Uang Ratusan Juta Rupiah dari Perhutani. Pikiran Rakyat Online News. 2019. Available online: https://www.pikiran-rakyat.com/jawa-barat/2019/03/13/29-lmdh-terima-uang-ratusan-juta-rupiahdari-perhutani (accessed on 27 June 2019).

77. Republic of Indonesia. The Government Regulation of Republic of Indonesia No. 15 Year 1972 Concerning Establishment of State-Owned Public Company; Republic of Indonesia: Jakarta, Indonesia, 1972.

78. Republic of Indonesia. The Government Regulation of Republic of Indonesia No. 38 Year 2007 Concerning Delegation of Authority from the Central Government to the Provincial and District Governments; Republic of Indonesia: Jakarta, Indonesia, 2007.

79. Republic of Indonesia. Blora District Regulation No. 25 Year 2001 Concerning Fees for the Harvesting Permit and or the Transportation of Timber from the People's Forest and Timber from Ex-Construction Sites; Republic of Indonesia: Jakarta, Indonesia, 2001.

80. Republic of Indonesia. Blora District Regulation No. 4 Year 2011 Concerning People's Forest Management and Forest Products' Administration; Republic of Indonesia: Jakarta, Indonesia, 2011.

81. Nguyen, T.Q. Forest devolution in Dak Lak, Vietnam: Improving forest management or livelihoods of the poor? In Hanging in the Balance: Equity in Community-based Natural Resource Management in Asia; Mahanty, S., Fox, J., Nurse, M., Stephen, P., McLees, L., Eds.; Regional Community Forestry Training Center for Asia and the South Pacific (RECOFTC) and East-West Center: Bangkok, Thailand, 2006; pp. 200-222.

82. Cousins, B.; Kepe, T. Decentralisation when land and resource rights are deeply contested: A case study of the Mkambati eco-tourism project on the wild coast of South Africa. Eur. J. Dev. Res. 2004, 16, 41-54. [CrossRef]

83. Pacheco, P.; Barry, D.; Cronkleton, P.; Larson, A.M. The Role of Informal Institutions in the Use of Forest Resources in Latin America; CIFOR: Bogor, Indonesia, 2008.

84. Sarin, M.; Singh, N.M.; Sundar, N.; Bhogal, R. Devolution as a Threat to Democratic Decision-making in Forestry? Findings from Three States in India; Overseas Development Institute: London, UK, 2003.

85. Maryudi, A.; Citraningtyas, E.R.; Purwanto, R.H.; Sadono, R.; Suryanto, P.; Riyanto, S.; Siswoko, B.D. The emerging power of peasant farmers in the tenurial conflicts over the uses of state forestland in Central Java, Indonesia. Policy Econ. 2016, 67, 70-75. [CrossRef]

86. Rosyadi, S. Good governance practices by local organization in forest resource management. J. Adm. Sci. Organ. 2012, 19, 28-33.

87. Bratamihardja, M.; Sunito, S.; Kartasubrata, J. Forest Management in Java 1975-1999: Towards Collaborative Management; Working Paper, No. 2005-1; ICRAFT Southeast Asia Regional Office: Bogor, Indonesia, 2005.

88. Peluso, N.L. Emergent forest and private land regimes in Java. J. Peasant Stud. 2011, 38, 811-836. [CrossRef] 
89. Maryudi, A. Kegagalan pengelolaan hutan Jawa. In Wacana: Rekonfigurasi Pengelolaan Hutan Jawa; Insist Press: Yogyakarta, Indonesia, 2011; pp. 75-94.

90. Maryudi, A. Restoring state control over forest resources through administrative procedures: Evidence from a community forestry programme in central Java, Indonesia. ASEAS Austrian J. South East Asian Stud. 2012, 5, 229-242.

91. Annual Report of the State Forest Corporation (SFC). 2017. Available online: http://www.perhutani.co.id/ laporan-perusahaan/laporan-tahunan/ (accessed on 27 June 2019).

92. Lee, J.; Kubo, Y.; Fujiwara, T.; Septiana, R.M.; Riyanto, S.; Iwasa, Y. Profit sharing as a management strategy for a state-owned teak plantation at high risk for illegal logging. Ecol. Econ. 2018, 149, 140-148. [CrossRef]

(C) 2019 by the authors. Licensee MDPI, Basel, Switzerland. This article is an open access article distributed under the terms and conditions of the Creative Commons Attribution (CC BY) license (http://creativecommons.org/licenses/by/4.0/). 